\title{
A KULTURÁLIS RELATIVIZMUS FOGALMI DISSZONANCIÁJA Hogyan értelmezhető a kulturális relativizmus az univerzális emberi jogok rendszerében? Kísérlet a kulturális relativizmus fogalmi tisztázására
}

\author{
CONCEPTUAL DISSONANCE OF CULTURAL RELATIVISM \\ How Can Cultural Relativism Be Interpreted in the system of Universal \\ Human Rights? An Attempt to Clarify the Term of Cultural Relativism
}

\author{
Takács Izolda \\ PhD, jogász, szociológus \\ izolda.t@hotmail.com
}

ÖSSZEFOGLALÁS

\begin{abstract}
A "kulturális relativizmus" kérdése a mai formájában a Bécsi Emberi Jogi Konferencián akkor került elő, amikor az iszlám és konfuciánus államok koalíciója elutasította a "nyugati univerzalizmust", abból kiindulva, hogy az emberi jogok modern kultúrája nyugati sajátosság. Tehát az emberi jogok univerzalizmusa és a kulturális relativista megközelítések közötti vita egyik alapproblémáját máig az jelenti, hogy az egyetemest általában a nyugati értékekkel azonosítják. Jelen tanulmányban a relativizmus, illetve a kulturális relativizmus fogalmi anomáliái kerülnek elő. Az első részben utalok arra, hogy maga a fogalom miért lehet problémás, majd a tartalmát illetően taglalom az e körül cirkuláló ellentmondásokat és logikai következetlenségeket. Hiszen a kiinduló probléma is éppen abból adódik, hogy a kulturális relativizmus terminusát kevesen határozzák meg pontosan, annak eredetét is szem előtt tartva. Ennek eredményeképpen pedig még ma is egy teljesen képlékeny fogalommal van dolgunk. Ugyanis a kulturális relativizmus nem jogi, de nem is a nevezett vita tárgyát összefoglaló, erre megalkotott fogalom, hanem az antropológiából és az erkölcsfilozófiából kölcsönözték. Utóbbi miatt a kulturális relativizmus fogalmát is legtöbb esetben magáról a relativizmusról folytatott nyilvános viták veszik körül.
\end{abstract}

\section{ABSTRACT}

The modern term of 'cultural relativism' first appeared at the World Conference on Human Rights in Vienna, 1953, when a coalition of Islamic and Confucian states rejected 'Western universalism'" on the ground that the modern culture of human rights is an exclusive Western feature. Thus, one of the fundamental problems regarding the debate of universalism of human rights versus cultural relativist even today is that universality is generally identified with Western values. The present study aims to provide the conceptual anomalies of the term of relativism and cultural 
relativism. In the first part, I try to present the concept issues of cultural relativism, and then I discuss the contradictions and logical inconsistencies circulating around the term. After all, the initial problem stems from the fact that the term of cultural relativism is precisely defined only by few who also considered its origin. As a result, we are still dealing with a completely fluid concept. Namely, cultural relativism is neither a legal concept, nor a concept created for the purpose of summarizing the subject of the debate (cultural relativism versus universalism), but was borrowed from anthropology and moral philosophy. And because of the later, the concept of cultural relativism in most cases is surrounded by public debates about relativism.

Kulcsszavak: emberi jogok, kulturális relativizmus, relativizmus, univerzalizmus

Keywords: human rights, cultural relativism, relativism, universalism

„Mert ha rábíznánk az emberekre, hogy válasszák ki, melyik szokást és hagyományt tartják a legszebbnek, végül is mindenki a maga szokásait választaná, hiszen a legjobban azt szeretjük, amit megszoktunk. Könnyen belátható, hogy ilyesmiből csak egy örült üzhet gúnyt. Hogy minden ember

így gondolkodik a saját szokásairól, azt sok példával lehetne bizonyítani, így azzal, hogy Dareiosz egyszer összehívta a nála időző helléneket, és megkérdezte, hogy mennyi pénzért ennék meg apjuk holttestét. Azok persze azt felelték, hogy nincs az a pénz, amiért megtennék. Dareiosz ekkor indeket - a kallatiesz nép tagjait - hívatott oda, akiknél az a hagyomány, hogy megeszik a meghalt apjukat, és a hellének előtt tolmácsok útján megkérdezte

tőlük, hogy mennyi pénzért égetnék el máglyán a halott atyáikat. Azok szörnyülködve kiabálni kezdtek, s kérve kérték Dareioszt, ne is ejtsen ki a száján efféle szavakat. Ilyen nagy tehát a szokások ereje, s véleményem szerint helyesen állítja Pindarosz költeményében, hogy »mindenen úr a szokás«." (Hérodotosz, 1998, 209.)

A „kulturális relativizmus” kérdése mai formájában a Bécsi Emberi Jogi Konferencián akkor került elö, amikor az iszlám és konfuciánus államok koalíciója elutasította a „nyugati univerzalizmust”. Ugyanis szerintük az emberi jogok modern kultúrája nyugati sajátosság, ezért nem rezonál az emberiség többi része számára (Huntington, 1998; Tierney, 2004). Holott magának az univerzalizmusnak a törekvése elvileg abban összegezhető, hogy az emberi jogok gyökere egy oszthatatlan, érinthetetlen univerzális emberi egység, amely az emberi méltóságból ered, és minden személyre ugyanúgy vonatkozik, abból kifolyólag, hogy ember. Az egyetemesség pedig azt jelentené, hogy a kultúra irreleváns ezen oszthatatlan, korlátozhatatlan alapjog és bizonyos szabályok érvényessége szempontjából. A kulturális relativizmus hívei, a fejlődő országok képviselői, illetve az egyes nyugati teoretikusok mégis azzal érvelnek, hogy minden erkölcsi érték, ideértve 
az emberi jogokat is, relatív, és szervesen csak ahhoz a kulturális környezethez idomulnak, ahol kialakultak. A szkeptikus álláspontok szerint ezért az emberi jogok globális rendjének utópiája csupán üres illúzió (Bielefeldt, 2000, 90.). Samuel P. Huntington A civilizációk összecsapása címü opusában pedig azon meggyöződésének adott hangot, hogy az emberi jogok egyetemessége kétségtelenül kudarcra van ítélve. Ezért az egyetlen járható út (miután a szerző úgy véli, a nyugati univerzalizmus a végéhez közelít) nem más, mint a kulturális relativizmus (Huntington, 1998). Az erős relativista álláspontot képviselő megközelítések szerint pedig az emberi jogok rendszere a „Nyugat” terméke, és még ma is gyarmatosító politikát képvisel, a Nyugattól való neokolonista függésre irányul, neoliberális politikája pedig ártalmas a harmadik világ országainak (Kondorosi, 2016, 29.). Ugyanakkor közelebbről szemlélve a két versengő megközelítést, azok logikailag sokkal kevésbé különböznek egymástól, mint ahogy elsőre gondolnánk. Az erős kulturális relativizmus csak egymás mellett létező, különböző zárt kultúrákat ismer el, amelyek közötti eltérések állításaik szerint feloldhatatlanok. Ám az univerzalizmus eszménye tulajdonképpen ugyancsak saját „zárt” értékrendszerének primátusát vallja, amellett, hogy ezt állítja be minden szempontból egyetemesnek (egy magasabbnak értékelt kultúrához képest relatív az ettől eltérö). Ezért éri az emberi jogok rendszerét az etnocentrikus arrogancia vádja. Ahogy erre Ludassy Mária is utalt: „,[a]z igazi kihívást nem az jelentette az emberjogi univerzalizmus számára, hogy vannak más kultúrák, melyek még nem jutottak el az emberi méltóság tiszteletének kulturális szintjére, hanem annak proklamálása, hogy az emberi jogok egyetemességének elve is csak egyike (még csak nem is legáltalánosabbika) a versengő kulturális szervezőelveknek" (Ludassy, 1999, 58.). Ezek fényében manapság legtöbben a két megközelítés között hidat képező mérsékelt kulturális relativizmus (több helyen relatív univerzalizmus) mellett kötelezték el magukat.

Emellett érvelt Kofi Annan ${ }^{1}$ is. Úgy véli, egyetlen emberi jogi modell, legyen az nyugati vagy nem nyugati, sem adhat kizárólagos mintát az összes állam számára. Ezért az emberi jogoknak elég rugalmasnak kell lenniük ahhoz, hogy teret engedjenek a különbségeknek, ám csak a hangsúlyok és a megvalósítás egyéni módszereinek tekintetében, de ezek semmiképpen nem érinthetik az alapvető jogok eltörlését, korlátozását vagy alárendelését más jogoknak (Le, 2016, 209.). Értelmezésem szerint a legnagyobb problémát az emberi jogok egységes fogalomalkotásában (overlapping consensus) alapvetően a kulturális relativizmus tartalmi elemeinek tisztázatlansága jelenti. A fogalmi zavar pedig abból adódik, hogy a kulturális relativizmus nem jogi, de nem is a nevezett vita tárgyát összefoglaló, erre megalkotott fogalom, hanem az antropológiából és az erkölcsfilozófiából kölcsönözték. Ezért a kulturális relativizmus fogalmát legtöbb esetben magáról a

\footnotetext{
${ }^{1}$ Kofi Annan (1938-2018), ghánai diplomata, 1997 és 2006 között az ENSZ 7. fötitkára.
} 
relativizmusról folytatott viták veszik körül (Baghramian-Carter, 2019). A relativizmus pedig az utóbbi évtizedekben vált igazán népszerüvé, főleg úgy, mint egy normatív-etikai és politikai nézőpontot alátámasztó teória.

\section{RELATIVIZMUS}

A relativizmus különböző típusainak közös kiindulópontja az az állítás, hogy az „X” jelenségek (értékek, esztétikai és etikai normák, tapasztalatok, ítéletek stb.) valamilyen módon mindig függnek az alapjukul szolgáló, független ,y” változóktól (paradigmák, kultúrák, fogalmi sémák, hitrendszerek, nyelv) és azokhoz társulnak. A függőség típusa pedig hatással van a meghatározások kérdéseire. Például (1) az adott dolog igaz, vagy igazságosnak tekinthető a helyi normákhoz viszonyítva, (2) vagy igaz a nyelv törvényeihez igazodva stb. (Baghramian-Carter, 2019).

Többen úgy tartják, hogy a relativizmust legkönnyebben úgy lehet meghatározni, ha megjelöljük azokat a fogalmakat, amelyeket egyértelmúen tagad. Ilyenek például az abszolutizmus, az objektivizmus, a monizmus, a realizmus. A negatív fogalomalkotás mentén közelíti meg a relativizmus fogalmát Vittorio Villa is a Relativism: A Conceptual Analysis címü írásában, de ő felsorolja azokat a fogalmakat, amelyekkel általában helytelenül azonosítják. Kihangsúlyozza, hogy amíg egyes területeken minden szempontból relatívat jelölünk vele (ezért a szubjektivizmussal kapcsoljuk össze), addig más esetekben már az abszolutizmussal ötvözzük. Ezen fogalmi anomáliák miatt egyes relativista gondolkodók, mint például Richard Rorty, egyenesen azt javasolják, hogy a legjobb lenne abbahagyni a relativizmus kifejezés használatát. Úgy véli, hogy nincs elegendő egységesség ahhoz, hogy bármilyen magyarázó vagy rekonstruktív funkciót végezhessen el a relativizmus terminusa (Villa, 2010, 171-172.). „Mi, pragmatikusok [...] soha nem nevezzük magunkat relativistának. Általában negatív fogalmakkal - »anti-platonista«, »anti-metafizikus « vagy »anti-fundacionalista« - határozzuk meg magunkat" (Rorty, 1995, 770.). Az úgynevezett pragmatikusok tehát abból indulnak ki, hogy a legtöbb dolog, amelyről a common sense azt állítja, hogy megtalált vagy felfedezett - ezért ezeket a tudományos vagy morális igazságokat „objektívakként" írják le -, igazából létrehozott (Rorty, 1995). A jogpozitivizmus képviselöi is, többek között Hans Kelsen, hasonlóan vélekednek. Úgy tartják, az igazságosság nem vezethető le objektív tételekből, így teljességgel kizárják azt a lehetőséget, hogy a normák a természetből dedukálhatók. Ezért minden értékrendszer tulajdonképpen társadalmi konstrukció. Bár kimondható, hogy vannak értékek, amelyekben a társadalmak és tagjaik között konszenzus van, attól még nem objektívek. Mindössze annak tünnek, mert konstitutív jelleget öltenek, de valójában relatívak (Kelsen, 1998). 
Ellenben, ha azt mondjuk, hogy az igazság nem lehet objektív, akkor itt már eleve logikai ellentmondásba ütközhetünk, mellyel maga a relativista álláspont a mai napig küzd. Merthogy, vajon mi a helyzet annak a mondatnak az igazságtartalmával, hogy: Az igazság nem egyetemes, az igazság mindig relatív? Akkor ez a mondat is relatív, vagy esetleg egyetemes? Mert, ha nem relatív ez az állítás, hanem univerzális (egyetemes relativizmus), akkor mégiscsak van legalább egy egyetemes igazság, viszont így már mégsem relatív összegészében.

Összefoglalva, ha igaz, hogy nem léteznek egyetemes erkölcsi alapelvek, akkor a relativisták mindig önellentmondásba kerülnek, ha kijelentik a relativista elv egyetemességét. Egyrészt ezzel azt állítják: (a) nincsenek egyetemes erkölcsi alapelvek; (b) minden csoportnak saját elveivel, törvényeivel összhangban kell eljárnia. Ám ez miért is nem egyetemes erkölcsi alapelv? Fernando R. Tesón úgy véli, a normatív relativizmusnak a következetlenség veszélyének elkerülése érdekében úgy kellene módosítani állításait, hogy: (a) nincsenek egyetemes erkölcsi alapelvek; (b) minden csoportnak saját elveivel összhangban kell eljárnia, és (c) az egyetlen általános erkölcsi elv a „b”. Sőt, ha a normatív relativista metaetikus, érvelése szerint még akkor sem tudja megmagyarázni, hogy a (b) pont miért nem egyetemes erkölcsi elv (Tesón, 1985, 888-889.). Ugyanezt a logikát alkalmazza Frederico Arcos Ramírez is. Első számú problémának azt tartja, hogy bár a relativista nézet elutasítja a különféle kultúrák és hagyományok objektív és független értékeinek meglétét, mégis filozófiaként mutatja be. Mégpedig olyanként, amely egyetlen objektív és transzkulturális elvet támogat, méghozzá az összes kultúra és az erkölcsi kódex toleranciáját. Ezzel viszont az erkölcsi relativista a normatív etika és a metaetika szintjén vagy (1) nem tudja megvédeni a toleranciát sem, mert tartózkodnia kell az erkölcsi ítéletek meghozatalától, vagy (2) a tolerancia védelmének is relatívnak kell lennie. Ezért a relativisták etikai szempontból nem mondhatnak semmit a tolerancia mellett vagy ellen, mert attól a pillanattól kezdve erkölcsi megfigyelői és védelmezői lennének. Ebből kifolyólag a tolerancia értéke nem a relativizmusból származik, hanem egyetemes erkölcsi követelménynek kell lennie (Arcos Ramírez, 2019, 187.). Ez alátámasztja azon érvelésemet is, miszerint úgy tünik, mégiscsak találtunk egy egyetemes értéket, méghozzá a toleranciát. Ezért teljesen logikusan megkérdezhetjük azt is, hogy ha létezik olyan módszer, mellyel felfedeztünk legalább egy univerzális elvet, akkor vajon - ahogy erre Tesón is utalt - több hasonlót miért ne lehetne találni?

Visszatérve a Relativism: A Conceptual Analysis címü tanulmányra, Villa tehát elutasítja Rorty azon javaslatát, hogy vessük el a relativizmus elnevezést. Megoldásként inkább a fogalom újradefiniálása, a relativizmus objektív minimumtartalmának kijelölése mellett érvel (Villa, 2010). E meghatározás szerint érvényesen relativistának kell tekinteni azokat a fogalmakat, amelyek szerint: ,a kognitív, kulturális, szemantikai, etikai, esztétikai stb. karakter kritériumainak minden (erős verzió), de legalább a jelentős része (gyenge verzió) a kontextustól függ, és ez 
minden alkalommal referenciapontként szerepel. Ez azt jelenti, hogy nincs olyan helyzet, nézőpont vagy paraméter, amely akármely kontextuson kívül lehetővé tenné ezen elemek teljesen semleges értékelését, így egy abszolút értelemben vett megerősítését vagy tagadását" (Villa, 2010, 173.). A kérdés az, ha a relativizmus fogalmát ily módon értelmezni próbáljuk, azzal vajon végleg megszabadultunk-e a tételeikkel kapcsolatos „fogalmi rémtől” és logikai következetlenségektől? Mert úgy tünik, a relativizmus nézetei még ekkor is kritika alá vonhatók, ezért csak megzavarják az egyetemes emberi jogok egységes fogalomalkotását. Összefoglalva, ha kijelentjük (ahogy Villa), hogy a relativizmus elismer bizonyos korlátokat és kritériumokat, ha ezzel nem vonjuk egy koordináta-rendszerbe azok összességét, ezzel miért is állítanánk logikailag mást, mint azok az antirelativisták, akik elismerik a jelentős kulturális különbségek tényét, de a látszólagos egyéni és kulturális különbségek mögött alapvető, közös vonásokra mutatnak rá, melyek az összes hitrendszerben és társadalmi-kulturális közegben közösek? Mint például az emberi méltóság minimumtartalma (vö. Baghramian-Carter, 2019).

\section{A KULTURÁLIS RELATIVIZMUS FOGALMÁNAK GENEALÓGIÁJA}

A relativizmus sokféle értelmezése közül elsősorban a leíró relativizmust használják a kulturális relativizmusról szóló filozófiai viták kiindulópontjaként, amely egy, a társadalmi antropológusok által alkalmazott empirikus és módszertani álláspont, és a 20. század második felében jött létre. Így a fogalmi disszonanciára a kulturális relativizmus vonatkozásában viszonylag logikus magyarázat van. A kulturális relativizmus mint fogalom (tkp. módszertani elv) eredetileg antropológusok olyan csoportjától származik, akik azt állították, hogy leginkább a kultúra és nem a biológia adhat magyarázatot az emberi viselkedések közötti különbségekre, utóbbit pedig a kölcsönös tisztelet és tolerancia által lehet áthidalni. Ugyanakkor, az (elsősorban amerikai) antropológusok csak fokozatosan próbálták javítani, pontosítani a kulturális relativizmus jelentését, ám utódaik türelmetlensége miatt mégis idő előtt bevonták a terminust az emberi jogokat, a multikulturalizmust érintő, illetve posztmodern vitákba, továbbá az erkölcsfilozófiába is (Hollinger, 2003). Eredetileg Franz Boas német származású amerikai antropológus határozta meg a kulturális relativizmus tartalmát, amely elmélet az antropológiai megközelítés ortodoxiájává vált. Eszerint ,az etnológia adatai bizonyítják, hogy mind tudásunk, mind érzelmeink azon társadalmi lét formáinak és emberek olyan történeteinek eredményeként jönnek létre, akikhez tartozunk” (idézi Hollinger, 2003, 708.). Illetve, ,,az etnológia adatainak ismerete azt is lehetővé teszi számunkra, hogy saját civilizációnkat objektív módon vizsgálhassuk" (Boas, 1940, 636.). Ennek a tételnek a tartalma Boas követője, Melville Jean Herskovits által került be a köztudatba, aki ezt úgy írta le, hogy ,[a]z ítéletek mindig a tapasztalatokon alapulnak, és a tapasztalatokat minden- 
ki saját kultúrájának mentén értelmezi” (idézi Hollinger, 2003). Herskovits megközelítése vált a kulturális relativizmus központi elemévé, ám 1955-ös nyilatkozatát félreértelmezték. Ugyanis többeknek azt sugallta a fent idézett mondat, mintha ezzel explicite azt állította volna, hogy a helyes és a rossz, valamint az igazság/igaz és a hamisság/hamis kérdései eltérő választ igényelnek az adott kultúrától függően. Sem ő, sem korának antropológusai nem szándékozták ezt ennyire sarkosan megfogalmazni. Ennek ellenére mégis a kulturális relativizmus ilyetén való meghatározását értették ki belőle, és ebben a formában vették át, mintegy jelezve, hogy az igazság és a jó minden esetben kizárólag a kultúrához viszonyul, vagy az egyik kultúra éppen olyan jó és igazságos, mint a másik. Ezért kerülhetett a fogalom helytelenül a mai disputákba is (Hollinger, 2003). Ezzel szemben Boas és Herskovits kijelentéséből világosan kifejeződik, kizárólag a kulturális relativizmus tényét mondták ki, azt, hogy az egyes szokások érvényesek egyik helyen, míg a másik helyen nem. Egyikük sem állította, hogy ezzel együtt minden esetben igaz vagy helyes is, ami az adott kultúrában megjelenik, csak azt, hogy igaznak vagy helyesnek értelmezik az abban élők. Sőt, azt még Boas is elismerte, hogy vannak bizonyos törvények, valószínűleg az emberiség kognitív tulajdonságain keresztül, amelyek nem véletlenül alakulnak ki, ugyanis hasonlóak két teljesen eltérő kultúrában is. Például, hogy nincsenek emberek vallás vagy müvészet nélkül, és hogy a társadalmi szervezet bizonyos formájában, a fejlődő kultúrákban az egyének szabadabbá válnak, mert eltünnek a magatartást irányító önkényes szabályok (Boas, 1940). Mindenesetre a kulturális relativizmus kifejezés, amely eredetileg helyesen a liberális értékek és a kozmopolita tolerancia megerősítését szolgálta volna, és ezzel vált ismertté, mégis olyan szük látókörü, zárt (parochial) kultúrák védelmével (vagy az azokkal szembeni közömbösséggel) társulhatott, amelyek például szentesítik a nőkkel szembeni elnyomást és visszaéléseket (Hollinger, 2003).

A tanulmányt bevezető, Hérodotosztól származó idézetben - melyből általában a szofisztika filozófiai relativizmusát olvassák ki - két egymással gyökeresen eltérő kultúrát ismerhetünk meg a görögök és a kallatiesznek nevezett indek (indiaiak) temetkezési szokásain keresztül. Ám a történettel valójában kizárólag a tolerancia (toleráns érdeklődés) fontosságára hívta fel a figyelmet Hérodotosz, amely fogalom paradoxon a relativizmus képviselöinek szótárában, hiszen az összehasonlítás lehetőségéról a relativizmus esetében nincs szó. De mit jelent a valódi tolerancia (toleráns érdeklődés), és hogyan valósul meg ott, ahol elvileg a legkisebb megértésre vagy egy másik kultúra elfogadására sincs lehetőség? Ezt a kérdést racionálisabban közelítette meg pont ezzel az idézettel kapcsolatban Karl Popper a Myth of the Framework címü müvében. Értelmezése, ellentétben a relativista nézetekkel, sokkal következetesebben függ össze a toleranciával. Érdemes megemlíteni az érveit, hogy közelebb kerüljünk a tolerancia fogalmának konceptualizálásához. Popper úgy véli, Hérodotosz volt az, aki felfedezte a kritikus és felvilágosult jellegü összecsapást a kultúrák között (cultural clash). Igazából ezen 
keresztül próbálta alátámasztani, hogy alapvetően minden vita gyümölcsöző annak alapján, hogy mit tudnak a résztvevők belőle tanulni (minél nagyobb a szakadék a vélemények között, szerinte annál gyümölcsözőbb lehet a vita, ha képesek vagyunk tanulni egymástól, vagy akár értékeket is átvenni). Minél érdekesebbek és bonyolultabbak a feltett kérdések, minél jobban megrendülnek a felek a másik nézetétől, világképétől, szokásaitól, annál jobban láthatják a dolgokat a maguk valójában (Popper, 1994). Szemben a kulturális relativizmussal, amelynek képviselői végső soron azt állítják, hogy a kultúrák zártak és összehasonlíthatatlanok egymással (például Oswald Spenglernél, Huntingtonnál), a nyelvi relativizmus álláspontja szerint, lásd Edward Sapir és Benjamin Lee Whorf hipotézisét, vannak bizonyos gondolatok, amelyeket nem tudnak megérteni azok, akik más nyelvi kontextusban léteznek (bár ennek is van erős és gyenge változata). Holott Hérodotosz, Popper szerint, azt akarta bebizonyítani, hogy nincsenek megváltoztathatatlan fogalmi keretek, és ezek egyik kultúra vonatkozásában sem statikusak. Úgy véli, hogy bár egy konfrontáció ritkán eredményez eredményes vitát, ugyanakkor ez az eset mégis eredményes volt, annak ellenére is, hogy a kölcsönös megértést nem sikerült elérni. Ugyanis valószínüleg mindkét felet megrázta ez a tapasztalat, és ami a legfontosabb, képesek voltak valami újat tanulni. Szerinte Hérodotosz demonstrálni próbálta, hogy először toleranciával kell közeledni a másik kultúrájához, majd megadni a lehetőséget a másik szokásainak kritikájához. Hiszen az egyik, a kallatiesznek nevezett indek kannibál szokása semmiképpen nem elfogadható. A tolerancia ebben az esetben nem azt jelenti, amit a relativistáknál jelentene, hogy mindkettő ugyanannyira jó, és nem lehet összehasonlítani a kettőt, sem azt, hogy az egyik egyáltalán nem lenne képes elmozdulni a saját keretéböl (Popper, 1994). Tovább gondolva mindezt, ezzel el is lehet vetni azt a tézist, hogy maga a kultúra koherens, homogén, statikus és zárt. Ezért az ilyetén való felfogása (ahogy az erős kulturális relativizmusnál, valamint az etnocentrizmusnál megjelenik) figyelmen kívül hagyja a kulturális kontingenciát, a folyamatos vita és a változás, azaz a fejlődés lehetőségét. Emiatt maga a tolerancia nem a relativizmus, hanem a mérsékelt/relatív univerzalizmus központi fogalma. Míg a relativizmus következetlenül alkalmazott „toleranciája” bár segít a másik kultúrájának elfogadásában, igazából közömbösséget jelent abban az esetben, ha az egyik meggyőződés vagy erőszakos, esetleg a nők vagy vallási, etnikai kisebbségek elnyomásán alapuló kulturális szokás kritika nélküli elfogadását jelenti vagy eredményezi. Ennélfogva csak arra jó, hogy megszabadítson bennünket annak terhétől és felelősségétől, hogy el kelljen dönteni, mely érvek a helyesebbek a másiknál (vö. Baghramian-Carter, 2019). A terminus bizonytalanságát jelzi az is, hogy az újabban született tanulmányok legtöbbje a kezdeti enyhébb/mérsékeltebb kulturális relativista szemlélettől is inkább a relatív univerzalizmus felé mozdult el (vagy ezt a kifejezést használják). Az elmúlt évtizedben pedig az erős relativista megközelítések nagy része teljesen el is tűnt a mainstream diskurzusokból. 


\section{IRODALOM}

Arcos Ramírez, F. (2019): The Challenge of Ethical-Cultural Pluralism to the Universality of Human Rights. The Age of Human Rights Journal, 12, 184-203. DOI: 10.17561/tahrj.n12.10, https://revistaselectronicas.ujaen.es/index.php/TAHRJ/article/view/4814/3837

Baghramian, M. - Carter, J. A. (2019): Relativism. In: Zalta, E. N. (ed.): The Stanford Encyclopedia of Philosophy. Winter 2019 Edition, https:// https://plato.stanford.edu/archives/win2019/ entries/relativism/ utolsó letöltés: 2020. 08. 15.

Bielefeldt, H. (2000): "Western" Versus "Islamic" Human Rights Conceptions?: A Critique of Cultural Essentialism in the Discussion of Human Rights. Political Theory, 28, 90-121. DOI: 10.1177/0090591700028001005, https://securitypolicylaw.syr.edu/wp-content/uploads/2013/03/ Beilefelt.2000.Cultural-Relativism-Critique.pdf

Boas, F. (1940): Race, Language and Culture. New York: The Macmillan Company

Donnelly, J. (2007): The Relative Universality of Human Rights. Human Rights Quarterly, 29(2), 281-306.

Hérodotosz (1998): A görög-perzsa háború. (ford. Muraközi Gy.) Budapest: Osiris Kiadó

Hollinger, D. (2003): Cultural Relativism. In: Porter, T. - Ross, D. (eds.): The Cambridge History of Science. Cambridge University Press, 708-720. DOI: 10.1017/CHOL9780521594424.043, https://www.researchgate.net/publication/297557855_Cultural_Relativism

Huntington, S. P. (1998): A civilizációk összecsapása és a világrend átalakulása. (ford. Puszta D., Gázsity M., Gecsényi Gy.) Budapest: Európa Kiadó

Kelsen, H. (1998): Mi az igazságosság? In: Varga Cs. (szerk.): Jog és filozófia Antológia a század elsö felének kontinentális jogi gondolkodása köréböl. Budapest: Osiris Kiadó, 202-218.

Kondorosi F. (2016): Emberi jogok és kultúrák. Eszmélet, 28, 109, 26-40. http://epa.oszk. hu/01700/01739/00094/pdf/EPA01739 eszmelet 109 026-040.pdf

Le, N. (2016): Are Human Rights Universal or Culturally Relative? In: Peace Review: A Journal of Social Justice, 28, 2, 203-211. DOI: 10.1080/10402659.2016.1166756, https://www.researchgate.net/publication/303359533_Are_Human_Rights_Universal_or_Culturally_Relative

Ludassy M. (1999): Egyetemes erkölcs versus etikai relativizmus (A francia felvilágosodás öröksége: multikulturalizmus vagy emberjogi univerzalizmus?). In: Csejtei D. - Laczkó S. (szerk.): Európai integráció - európai filozófia. Szeged: Pro Philosophia Szegediensi Alapítvány, 1732. http://acta.bibl.u-szeged.hu/9480/1/esz_006_040-059.pdf

Popper, K. (1994): Myth of the Framework. In: Notturn, M. A. (ed.): Defence of Science and Rationality. London: Routledge, 33-64.

Rorty, R. (1995): Relativizmus: megtalálni és létrehozni. (ford. Boros J.) Jelenkor, Irodalmi és művészeti folyóirat, 38(9), 769-780. http://www.jelenkor.net/userfiles/archivum/1995-9.pdf

Tesón, F. R. (1985): International Human Rights and Cultural Relativism. Virginia Journal of International Law, 25, 869-898. https://ir.law.fsu.edu/cgi/viewcontent.cgi?article=1038\&context $=$ articles

Tierney, B. (2004): The Idea of Natural Rights-Origins and Persistence. Northwestern Journal of International Human Rights, 1.

Villa, V. (2010): Relativism: A Conceptual Analysis. Edios, 13, 166-191. http://www.scielo.org.co/ pdf/eidos/n13/n13a09.pdf 